\title{
Primary Hepatic Lymphoma: A Complex and Challenging Diagnosis
}

\author{
Rinku Joshi', Pritanjali Singh ${ }^{2}$, Dhan Bahadur Shrestha ${ }^{3}$
}

\begin{abstract}
${ }^{1}$ Department of Medicine, ${ }^{3}$ Medical Student; Nepalese Army Institute of Health Sciences, Shree Birendra Hospital, Kathmandu, Nepal; ${ }^{2}$ Department of Radiotherapy, All India Institute of Health Sciences, Patna, India.
\end{abstract}

\section{ABSTRACT}

Primary hepatic lymphoma is the rare condition affecting liver and presents to clinician as space occupying lesion and is an extranodal variety of non-Hodgkin lymphoma. The diagnosis is based on the suspicious eye with keen laboratory investigation after ruling out the other common pathologies of the liver which presents as space occupying lesion.

Here we present a case who presented to us with dull pain and swelling right upper abdomen accompanied by prodromal symptoms which after proper work up was diagnosed as primary diffuse large B-cell non-Hodgkin lymphoma (NHL) of liver.

Keywords: non-hodgkin lymphoma; primary hepatic lymphoma; chemotherapy

\section{INTRODUCTION}

Primary hepatic lymphoma (PHL) is an uncommon subset of extranodal lymphoma that accounts for $<$ $1 \%$ of all extranodal lymphomas. ${ }^{1,2}$ Misdiagnosis and mistreatment is very frequent because of its rarity, non-specific clinical symptoms, laboratory and radiological resemblance to other space occupying liver lesions like focal nodular hyperplasia, primary hepatocellular carcinoma (HCC), carcinoma with hepatic metastases, and systemic lymphoma with secondary hepatic involvement. ${ }^{3-5}$

Here we present a case of an immunocompetent young male patient with primary diffuse large Bcells non-Hodgkin lymphoma (NHL) presenting as dull pain and swelling right upper abdomen accompanied by prodromal symptoms.

\section{CASE REPORT}

A 20-year-old student with no significant prior medical and family history presented to our hospital with 2-month history of dragging pain in the right upper quadrant, relieved with analgesics. Abdominal pain was accompanied by swelling over the same region, fever, loss of appetite, and night sweats. He did not mention having vomiting, diarrhea, blood in stools, jaundice or weight loss.

On clinical examination, there was mild pallor, a temperature of $38.5^{\circ} \mathrm{C}\left(101.3{ }^{\circ} \mathrm{F}\right)$, pulse rate of 96 beats per minutes and blood pressure of $100 / 70 \mathrm{~mm}$ $\mathrm{Hg}$. There was non-tender hepatomegaly with the liver span of $16 \mathrm{~cm}$. However, there were no signs of liver disease including jaundice, ascites and splenomegaly. No peripheral lymphadenopathy was appreciated. Scrotal examination was normal. Other systemic findings were unremarkable.

Laboratory tests revealed a normocytic anemia with hemoglobin level of $10.6 \mathrm{gm} \%$ and a normal WBC count with a normal differentiation. Renal function test with electrolytes, liver-function tests, carcinoembryonic antigen (CEA), CA 19-9, and $\alpha$ -
This work is licensed under: http:// creativecommons.org/licenses/by-nc-nd/4.0/

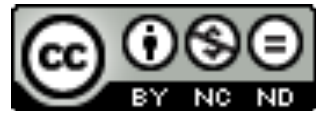

Correspondence: Rinku Joshi, Department of Medicine, Nepalese Army Institute of Health Sciences, Shree Birendra Hospital, Kathmandu, Nepal.Email:_rrinkujoshi@gmail.com 

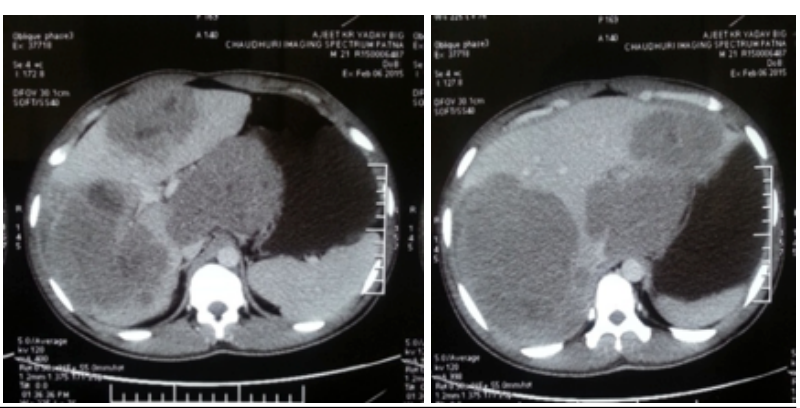

Figure 1: CT scan showing multiple hypoechoic lesions with internal septation in both lobes of liver

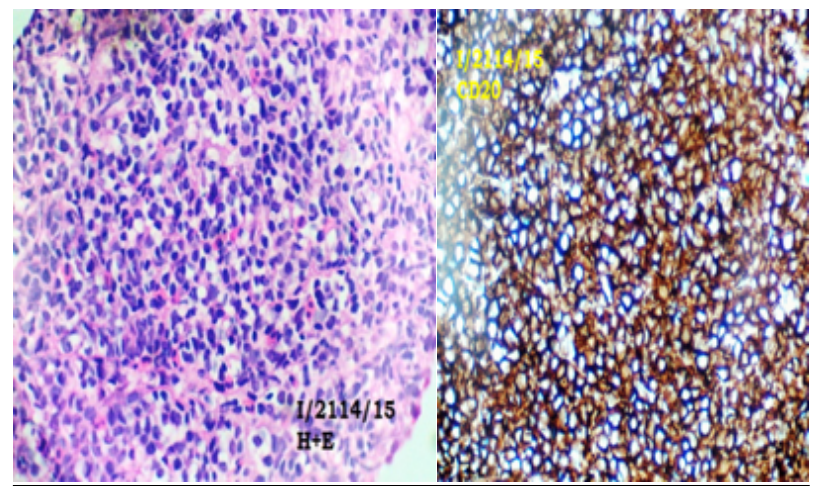

Figure 2: (a) $\mathrm{An} \mathrm{H}$ and $\mathrm{E}$ picture showing diffuse infiltration by sheets of small- to-intermediate atypical cells. (b) An IHC picture showing CD20 positive tumour cells, proving B-cell lineage.

fetoprotein were all normal. Serology was negative for HIV, Hepatitis C and B virus. Serum calcium level was not elevated. However, lactate dehydrogenase (LDH) was markedly raised (2379 $\mathrm{U} / \mathrm{L})$.

Radiology of chest did not reveal any mediastinal lymphadenopathy. Abdominal ultrasound depicted multiple hypoechoic lesions with internal echogenic septation in both lobes of liver with exophytic component in gastro-hepatic region. Abdominal computed tomography (CT) scan showed well defined, homogenous, hypodense, minimally /non-enhanced space occupying lesions with geographical lobulated borders, one each in right lobe, left lobe \& caudate lobe of liver, largest about $15 \times 12 \mathrm{~cm}$ in right lobe. (Figure 1)

The possibility of malignant mass of liver was made at this stage. Ultrasound (USG) guided fine needle aspiration cytology (FNAC) was done which revealed findings consistent with NHL. He further underwent USG guided trucut biopsy from the right liver lobe nodule which showed diffuse infiltrates of small to intermediate atypical sized round cells with oval to indented nuclei, dark smudged chromatin and inconspicuous nucleoli with scanty cytoplasm, admixed with few small lymphocytes and eosinophils (Figure 2(a)).

Immunohistochemical (IHC) staining demonstrated CD20 positive cells and confirmed the presence of cells of the B-lymphocyte lineage (Figure 2(b)).

Considering the rarity of PHL, bone marrow biopsy was advised which showed normal cellularity with trilineage haematopoiesis in normal proportion. CTscan chest showed no other foci of lymphoma in the body.

Considering liver to be the only site of lymphoma, he received the diagnosis of PHL, Stage IVEBX. He was promptly started on 6 cycles of R-CHOP regimen based on his BSA. On subsequent follow up, improvements were markedly observed in terms of clinical, laboratory and radiological parameters. (Figure 3)

\section{DISCUSSION}

Extranodal lymphomas are responsible for $10 \%$ to $25 \%$ of NHL. ${ }^{2,6}$ Of all primary extranodal NHL only $0.4 \%$ arises in the liver. ${ }^{2}$ The incidence of hepatic involvement in NHL is described between $16 \%$ and $22 \% .^{7}$ The etiology of this disease may have an association with viral infections, liver cirrhosis, primary biliary cirrhosis, immunosuppressive therapy and autoimmune disease. ${ }^{8}$ However, our patient had none of these.

PHL typically occurs in middle-aged men (median age, 50 to 55 years $)^{9,10}$, with the most common presentation being pain in the right upper quadrant, fever, weight loss, and night sweats as were present in our patient. ${ }^{9-12}$ Prodromal symptoms may accompany these symptoms. ${ }^{9,11}$ A physical examination commonly reveals hepatomegaly (in approximately $80 \%$ of cases) and, less frequently, jaundice, splenomegaly, ascites, or pleural effusions. An incidental diagnosis without preceding symptoms has been reported in $10 \%$ of patients. ${ }^{9}$ Diffuse and infiltrative histologic patterns have been reported, with diffuse one being predominant ${ }^{13}$, as was true for our patient. Other types $(<5 \%)$ are immunoblastic, lymphoblastic, Burkitt's lymphomas, mucosa-associated lymphoid tissue lymphomas, anaplastic large-cell lymphoma, and rarely $\mathrm{T}$ cell type. 

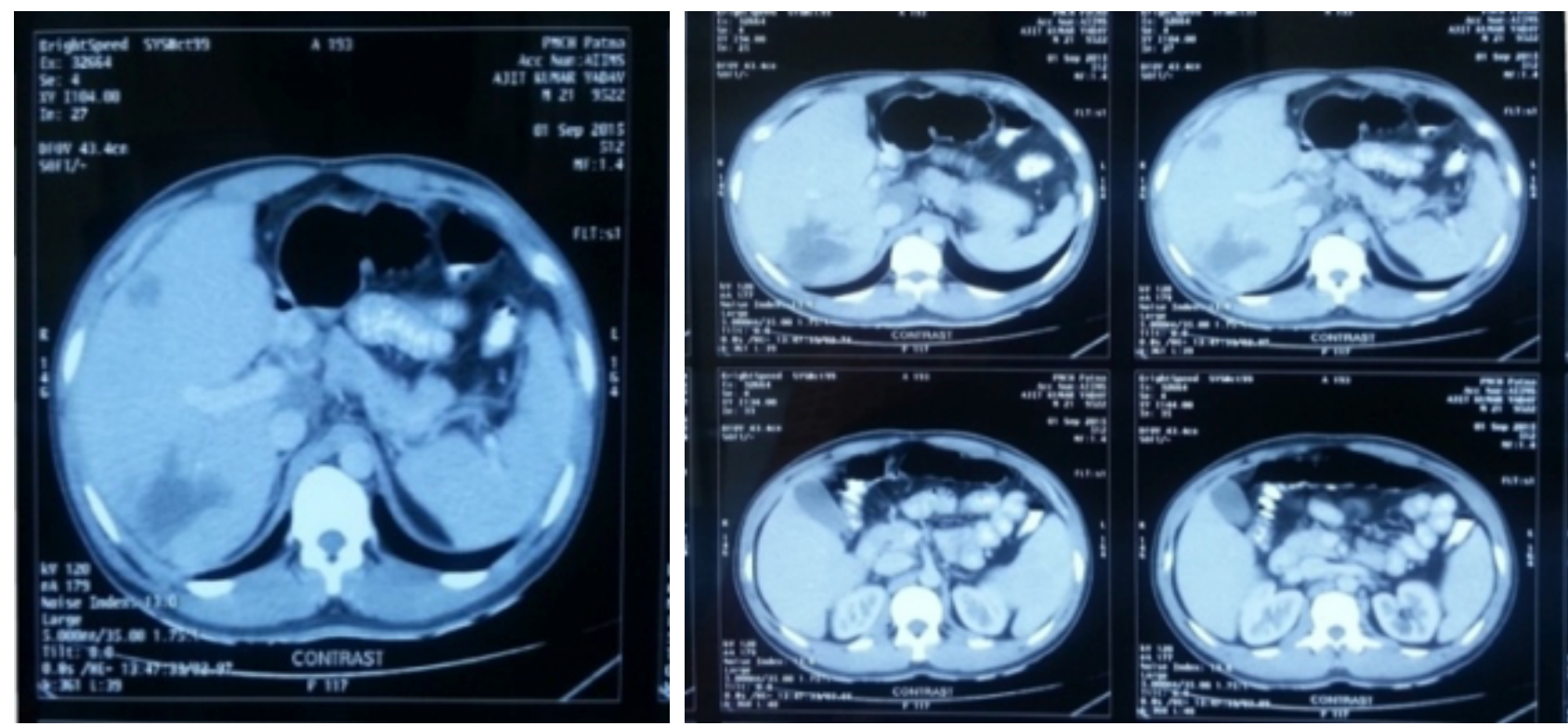

Figure 3: Repeat contrast abdominal CT (after 6 cycles of CHOP) scan showing marked regression in size of liver nodules.

Laboratory findings usually include abnormal liver enzymes, lactate dehydrogenase, and $\beta$ microglubulin, with an almost invariably normal $\alpha$ fetoprotein and carcinoembryonic antigen. Hypercalcemia is observed in $40 \%$ of patients possibly due to release of calcitriol by malignant lymphoma cells. Ultrasound is a simple, noninvasive and good screening test, which classically shows hypo-echoic lesions. ${ }^{13,14}$ The abdominal CT scan shows hypo-attenuating masses, unenhanced or poorly enhanced after contrast. The findings with magnetic resonance imaging may shows hypo-intense lesions on $\mathrm{T}_{1}$ weighted and hyper-intense in $\mathrm{T}_{2}$-weighted.,13-16 Liver biopsy remains the most valuable tool for diagnosis of PHL (percutaneous / transjugular). Immunohistochemical typing is needed to differentiate lymphoma from other malignancies.

Surgery, chemotherapy, and radiotherapy are treatment options of PHL. R-CHOP is used for $\mathrm{CD} 20^{+}$tumors. ${ }^{17-21}$ Surgery is indicated for localized disease and surgical debulking before or after chemotherapy. Adjuvant chemotherapy after complete surgical resection results in complete remission of disease. ${ }^{10}$

Poor prognostic features include advanced age, constitutional symptoms, bulky disease, unfavorable histologic subtype, elevated levels of LDH and $\beta 2$-microglobulin, a high proliferation rate, cirrhosis, and comorbid conditions. ${ }^{21}$ The appreciation of prognostic factors in our patient through the assessment of these prognostic features enabled us to predict a moderately good prognosis.

\section{CONCLUSIONS}

PHL is a rare entity that should be considered as differential diagnosis of space occupying liver lesions with normal levels of alpha-fetoprotein and CEA. The rarity of the disease leads to problems of diagnosis and management. If the clinical picture and imaging findings on CT scans and MRI are nonspecific, a liver biopsy is needed not only for a definitive diagnosis but also for identifying the immunophenotype of the lesion.

It is important to recognize PHL because it is chemosensitive and may have a better prognosis than hepatocellular carcinoma or metastatic disease of the liver. Surgery may be proposed in the nodular forms, with adjuvant chemotherapy; which is highly recommended to reduce the rate of extrahepatic recurrence.

\section{REFERENCES}

1. Agmon-Levin N, Berger I, Shtalrid M, Schlanger H, Sthoeger ZM. Primary hepatic lymphoma: a case report and review of the literature. Age Ageing. 2004;33:63740. DOI: https://doi.org/10.1093/ageing/afh197 PMid: 15381504

2. Freeman C, Berg JW, Cutler SJ. Occurrence and prognosis of extranodal lymphomas. Cancer. 1972;29:252-60. DOI: https://doi.org/ 10.1002/1097-0142(197201)29:1<252::AIDCNCR2820290138>3.0.CO;2-\# 
3. Avlonitis VS, Linos D. Primary hepatic lymphoma: a review. Eur J Surg. 1999;165:725-29. DOI: https:// doi.org/10.1080/11024159950189474 PMid:10494635

4. Yang XW, Tan WF, Yu WL, Shi S, Wang Y, Zhang YL. et al. Diagnosis and surgical treatment of primary hepatic lymphoma. World J Gastroenterol. 2010 Dec $21 ; 16$ ( 47 ):6016-9. P M id:21157979 PMCid:PMC3007103

5. Chen HW, Sheu JC, Lin WC, Tsang YM, Liu KL. Primary liver lymphoma in a patient with chronic hepatitis C. J Formos Med Assoc. 2006;105:242-6. DOI: https://doi.org/10.1016/S0929-6646(09)60313-2

6. Rudders RA, Ross ME, DeLellis RA. Primary extranodal lymphoma: Response to treatment and factors influencing prognosis. Cancer. 1978 Aug 1;42(2): $406-16$. D O I : h t t p s : / / d o i o r g / $10.1002 / 1097-0142(197808) 42: 2<406:$ :AID cNCR2820420205>3.0.CO;2-H

7. Civardi G, Vallisa D, Bertè R, Lazzaro A, Moroni CF, Cavanna L. Focal liver lesions in non-Hodgkin's lymphoma: Investigation of their prevalence, clinical significance and the role of Hepatitis $\mathrm{C}$ virus infection. Eur J Cancer. 2002;38:2382-7. DOI: https://doi.org/ $\underline{10.1016 / \mathrm{S} 0959-8049(02) 00481-1}$

8. Santos ES, Raez LE, Salvatierra J, Morgensztern D, Shanmugan N, Neff GW. Primary hepatic non-Hodgkin's lymphomas: case report and review of the literature. Am J Gastroenterol. 2003;98:2789-93. DOI: https://doi.org/ 10.1111/j.1572-0241.2003.08766.x PMid:14687834

9. Lei KI. Primary non-Hodgkin's lymphoma of the liver. Leuk Lymphoma. 1998 Apr;29(3-4):293-9. DOI: https://doi.org/10.3109/10428199809068566 PMid: 9684927

10. Page RD, Romaguera JE, Osborne B, Medeiros LJ, Rodriguez J, North L. et al. Primary hepatic lymphoma. Cancer. 2001 Oct 15;92(8):2023-9. DOI: https://doi.org/ 10.1002/1097-0142(20011015)92:8<2023::AIDCNCR1540>3.0.CO;2-B

11. Anthony PP, Sarsfield P, Clarke T. Primary lymphoma of the liver: clinical and pathological features of 10 patients. Journal of clinical pathology. $1990 \mathrm{Dec}$ 1;43(12):1007-13. DOI: https://doi.org/10.1136/jcp. 43.12.1007 PMid:2266172 PMCid:PMC502974

12. Osborne BM, Butler JJ, Guarda LA. Primary lymphoma of the liver ten cases and a review of the literature. Cancer. 1985 Dec 15;56(12):2902-10. DOI: $\begin{array}{lllllllllllllllll}\mathrm{h} & \mathrm{t} & \mathrm{t} & \mathrm{p} & \mathrm{s} & \mathrm{l} & / & / & \mathrm{d} & \mathrm{o} & \mathrm{i} & . & \mathrm{o} & \mathrm{r} & \mathrm{g} & /\end{array}$ 10.1002/1097-0142(19851215)56:12<2902::AIDCNCR2820561230>3.0.CO;2-W

13. Noronha V, Shafi NQ, Obando JA, Kummar S. Primary non-Hodgkin's lymphoma of the liver. Crit Rev
Oncol Hematol. 2005;53:199-207. DOI: https://doi.org/ 10.1016/j.critrevonc.2004.10.010 PMid:15718146

14. Maher MM, McDermott SR, Fenlon HM, Conroy D, O'Keane JC, Carney DN. et al. Imaging of primary nonHodgkin's lymphoma of the liver. Clin Radiol. 2001 Apr; 56(4):295-301. DOI: https://doi.org/10.1053/crad. 2000.0649 PMid:11286581

15. Soyer P, Van Beers B, Grandin C, Pringot J, Levesque M. Primary lymphoma of the liver: MR findings.Eur J Radiol. 1993;16:209-212. DOI: https:// doi.org/10.1016/0720-048X(93)90074-W

16. Weissleder R1, Stark DD, Elizondo G, Hahn PF, Compton C, Saini S. et al. MRI of hepatic lymphoma. Magn Reson Imaging. 1988 Nov-Dec;6(6):675-81. DOI: https://doi.org/10.1016/0730-725X(88)90092-6

17. Coiffier B, Lepage E, Brière J, Herbrecht R, Tilly H, Bouabdallah R, Morel P, Van Den Neste E, Salles G, Gaulard P, Reyes F. CHOP chemotherapy plus rituximab compared with CHOP alone in elderly patients with diffuse large-B-cell lymphoma. N Engl J Med. 2002 Jan 24;346(4):235-42. DOI: https://doi.org/10.1056/ NEJMoa011795 PMid:11807147

18. De Renzo A, Perna F, Persico M, Notaro R, Mainolfi C, De Sio I. et al. Excellent prognosis and prevalence of HCV infection of primary hepatic and splenic non-Hodgkin's lymphoma. Eur J Haematol. 2008 Jul 1;81(1):51-7. DOI: https://doi.org/10.1111/j. 1600-0609.2008.01081.x PMid:18397390

19. Serrano-Navarro I, Rodríguez-López JF, NavasEspejo R, Pérez-Jacoiste MA, Martínez-González MA, Grande C. et al. Primary hepatic lymphoma-favorable outcome with chemotherapy plus rituximab. Rev Esp Enferm Dig . 2008 Nov;100(11):724-8. PMid:19159179

20. Zafar MS, Aggarwal S, Bhalla S. Complete response to chemotherapy in primary hepatic lymphoma. J Cancer Res Ther . 2012 Jan 1;8(1): 114-6. DOI: https://doi.org/ 10.4103/0973-1482.95187 PMid:22531527

21. Masood A, Kairouz S, Hudhud KH, Hegazi AZ, Banu A, Gupta NC. Primary non-Hodgkin lymphoma of liver. Curr Oncol. 2009 Aug;16(4): 74-7. DOI: https:// doi.org/10.3747/co.v16i4.443 PMid:19672429 PMCid:PMC2722057 